\title{
Potential of Pindang Bandeng as The Betawi-Tionghoa Acculturation Food Iconic Product
}

\author{
Rustini $^{1}$, Lila Muliani ${ }^{2}$ \\ \{niny_hiers@yahoo.com ${ }^{1}$, lilamuliani@gmail.com² \\ Institut Ilmu Sosial dan Manajemen Stiami, Indonesia ${ }^{1,2}$
}

\begin{abstract}
Pindang Bandeng for the Betawi people is a part of The Non-Material Culture Heritage owned by the Jakarta Capital Special Region which is now increasingly marginalized. The object of this Internal Grant Research is to increase the potential of Pindang Bandeng as a Betawi-Chinese acculturation food iconic. This Internal Grant Research used qualitative research which will result in findings without the assistance of statistical procedure or form of calculations in their analysis. This research was conducted using Purposive Sampling sample technique. The primary data of this research was carried out through Focus Group Discussion/FGD and in-depth interviews and observation. The data of this research was analyzed by Grounded Theory. While secondary data was taken from various written sources and documentation. The results of this research could be concluded that Pindang Bandeng could be raised its potential as the Betawi-Chinese Acculturation Food Iconic Product, wherein it was a food product of the blend of Betawi and Chinese cultures especially during Chinese New Year because it was identical with milkfish processed into Pindang Bandeng. Thus, Pindang Bandeng became an Icon of Chinese New Year celebration in Indonesia.
\end{abstract}

Keywords: Iconic Product, Acculturation, Betawi, Chinese, Grounded Theory.

\section{Introduction}

\subsection{Research Background}

United Nations Educational, Scientific and Culture Organization divided world heritage into two, namely world natural heritage and world culture heritage. Definition of world culture heritage in Indonesia was a region having an extraordinary universal value and a very important influence on the culture that is within the territory of the Unitary Republic of Indonesia and determined by UNESCO.

Furthermore, culture heritage was divided into two, namely material and non-material. Material culture heritage is things that can be touched and used (tangible). Meanwhile, the definition of Non-Material Culture Heritage according to the Ministry of Education and Cultural (Kemdikbud) was all practices, representations, expressions, knowledges, skills - as well as tools, objects (natural), artifacts, and culture spaces associated with them - recognized by various communities, groups, and in certain cases individuals as part of their culture heritage. Culinary was included in the category of Non-Material Culture Heritage.

In the Regional Regulation (Perda) of the Jakarta Capital Special Region Number 4 of 2015 in Article 1 number 26, it is stated that Culinary was all types of food characterizing 
Betawi, wherein Betawi culinary was included in the element of Betawi Cultural Conservation Implementasion mentioned in Article 9 of the same Perda.

In article 8 of the said Perda, the community was obliged to conserve Betawi culture and can participate in Betawi Cultural Conservation effort, especially in:

a. Inventoring the values of Betawi culture tradition;

b. Inventoring the culture assets and extracting the Betawi history; c. Increasing Betawi Culture Conservation activity;

c. Disseminating and publishing the values of Betawi culture tradition; and

d. Facilitating the development of human resources quality in Betawi Culture Conservation Pindang Bandeng, a Betawi culinary, for the Betawi community is a part of the NonMaterial

Culture Heritage owned by the Jakarta Capital Special Region. It is now increasingly marginalized since it is less well known by the younger generation who prefer junk food as their favorite food.

Speaking about Pindang Bandeng Betawi, it could not be separated from Chinese New Year celebration in Indonesia. Since the 17th century, milkfish (Bandeng) has been used in Chinese New Year celebration in Indonesia as a celebration of welcoming spring. The Chinese New Year itself for Betawi community has been considered as their own culture, it was proven that the Betawi community called Imlek as "Lebaran China". This happened because of the acculturation of Chinese culture with Local culture (Betawi).

\subsection{Formulation of Problem}

Can the potential of Pindang Bandeng be increased as a Betawi-Chinese Acculturation Food Iconic Product?

\subsection{Research Purposes}

The purpose of this research was to increase the potential of Pindang Bandeng as an Betawi-Chinese Acculturation Food Iconic Product culture.

\subsection{Advantages of Research}

The results of this research were expected to provide information and advantages for:

a. Practitioner (Tourism Industry)

Providing information for practitioners could be used as consideration in making long-term decisions in related fields.

b. The development of upcoming science/theory

This research was also expected to contribute to the development of science of subsequent researches.

\section{Methods}

\subsection{Teoritical Concept}

This chapter discussed concepts and theories relating to Iconic Product and Food Acculturation, which would provide a broader understanding of this research. 


\subsection{Iconic Product Concept}

Iconic product is a product becoming an icon or a symbol as consumer's reminder of the symbols contained in the said product. While Icon is a symbol having similar appearance and the said symbol is not difficult for the wearer to recognize. Within icon, the relationship between the representmen and the object is embodied in the same quality. Meanwhile, the Iconic Brand is a brand owned by consumer who with the certain understanding and experience with specific brand, the said consumer becomes very close to the brand and even feels that the brand has become a part of him (Ahmad Hanfan, 2017).

According to Holt (2004), there are four main elements to create an iconic brand, namely:

1. The product performance must be received, preferably having good quality.

2. A meaningful culture story is made by community. This must be seen as something that is legitimate and respected by consumers for the stories received.

3. Some types of discrepancies between prevailing and hidden ideologies appear in society. In other words, there are differences in how consumers consume and how they have hope.

4. Actively involved in the process of making myths, ensuring the brand maintains its position as an icon. In this case, Pindang Bandeng has become an iconic product of the Betawi community when Chinese New Year. The existence of Pindang Bandeng in Chinese New Year celebration has become a part of the cultural of the Betawi community and it was incomplete without Pindang Bandeng decorating the dining table during the Chinese New Year celebration.

\subsection{Acculturation Concept}

Acculturation is a social process araising when a group of community with a particular cultural is confronted with elements of foreign cultural in such a way that the said elements of foreign culture are gradually accepted and processed into their own cultural without causing the loss of the local cultural itself (Koentjaraningrat, 1990 )

The selection process of foreign culture elements by local residents occurs in the process of acculturation. An example of the selection process of foreign culture elements and developed into a new culture in terms of Pindang Bandeng was that this culinary has been used for Chinese New Year celebration since the 17th century in Indonesia, but in its own country, China, this milkfish not found.

Thus, this milkfish is as an alternative adapted to Betawi cultural.

The process of selective absorption and the rejection of elements of foreign culture by the community was occured in a relatively long period of time, so that the process of cultural change through acculturation still contains elements of genuine local culture.

\subsection{Methods}

This research was a qualitative research using descriptive data can be written or oral words from people who were researched or observed. According to Anselm Strauss and Juliet Corbin (2015), qualitative research is a research resulting findings without the assistance of statistical procedure or form of calculation in their analysis.

This research was conducted using Purposive Sampling sample technique. Purposive sampling is withdrawal or sampling/research informant purposively, namely the determination of informant with certain conditions. In this research, the requirements of the informant taken were expert who had deep knowledge of Betawi typical traditional culinary. The key 
informants in this research were Mrs. Cucu Sulaicha and Mrs. Anisa Diah Sitawati. Other informants were Mrs. Suzen HR Lumban Tobing, Mr. Yahya Andi Saputra and Mr. Heryus Saputra.

The primary data of this research was carried out through Focus Group Discussion/FGD and in-depth interviews and observation. The data of this research was analyzed by Grounded Theory. While secondary data was taken from various written sources and documentation.

The method used in this research was Grounded Theory, which was a research strategy wherein researcher "produce" general theory and abstract of a particular process, action, or interaction coming from the views of participants. This design requires a researcher to undergo a plurality of stages of data collection and filtering of categories of information obtained.

Grounded Theory develops a new theory from the data obtained, not testing the theory as was done in other research methods. To produce a gounded theory, a researcher must work in the field throughout the research. Methods of interviewing, direct observation, census data, questionnaire data, or other types of data must be recorded carefully and completely.

The stages of research in Grounded Theory were carefully designed to meet the criteria of the scientific method. The intended criteria was the existence of significance, compatibility between theory and observation, coud be generalized, could be re-examined, the existence of pertinence and accuracy, and the said criteria can be proven.

The location of the research was conducted in Rawabelong, West Jakarta and surrounding areas. The choice of this location was based on the reason this area was indeed a center of milkfish at the time of the Chinese New Year. The Chinese night market filled with milkfish sellers was reported to have started since the 1960s.

\section{Result And Discussion}

\subsection{Culinary History}

In Indonesia, Pindang Bandeng culinary is not a new menu. For Betawi people, milkfishbased culinary is very popular and has become a favorite daily menu, so in several other regions in Indonesia. However, maybe many people do not know if the history of Pindang Bandeng is very long and Chinese culture is reported to influence the taste of this culinary.

In a Betawi shop or restaurant we can usually find this menu, such as at the Ketupat Sayur Restaurant H. Mahmud in Kebayoran Lama or at Kafe Betawi in malls.

In the tradition of Chinese people living in Indonesia, milkfish is always served during Chinese New Year celebration. Fish for Chinese is a symbol of prosperity and sustenance. The word "fish" in Chinese accent or pronunciation is the same as "Yu" which means sustenance. They hope that they will gain prosperity and sustenance in the newyear. Meanwhile, burrs in milkfish symbolize the complexity of life. Therefore, we need to be careful in eating milkfish, as same as we go through this life.

According to historian J.J. Rizal, milkfish in Chinese New Year dish was only available in Indonesia. There was not available in China. Jakarta Chinese actually absorb milkfish from Betawi culture since the 17th century. He continued, the mentioning of "Lebaran China" as another name for Chinese New Year by the Betawi people showed the acceptance of Betawi people towards Chinese New Year itself, and even they joined in looking for Chinese New Year dishes. Thus, for Chinese people, milkfish was an alternative fish in Chinese New Year celebration. 
For what is Chinese New Year milkfish? For pindang made. Why is milkfish in Chinese New Year celebration? According to Bang Rudi from the Betawi Cultural Institute (Lembaga Kebudayaan Betawi - LKB), because only milkfish that can live easily in the coastal waters of Jakarta. However, there were also fishermen who purposively raising milkfishes for a year and they sold them during the Chinese New Year. That was why the size of the milkfishes was large, at least 2 kilograms and even the largest one reaches 7 kilograms.

The matchmaking/acculturation of the two cultures between Betawi culture and Chinese culture has been held for a long time before the arrival of the Dutch who eventually ruled Indonesia for hundreds of years. The results of the said matchmaking could be seen for example in the culinary field. In the celebration of Chinese New Year, not only the Chinese ethnic who were busy welcoming the celebration of the said Chinese New Year, but the Betawi community were, too, especially the Betawi community around Kebon, Jeruk, Rawabelong and Palmerah. The Betawi community in the said areas was busy looking for the large milkfishes to be cooked as pindang, as if milkfish was a must item during the Chinese New Year.

The tradition occured in some Betawi communities from generation to generation during the Chinese New Year was to deliver or "ngejot" milkfish to parent-in-law. In past, a son-inlaw who did not deliver milkfish in Chinese New Year could be considered or labeled as a stingy son-in-law. On the other hand, the son-in-law delivered her parent-in-law with a large milkfish which if it carried up to "ngengser" (fell off) its tail, then the said son-in-law would be "disohor" or praised and proud of his parent-in-law. However, today, the tradition has begun to fade, since milkfish was mostly bought to be eaten with family or shared with neighbors.

According to Mrs. Cucu Sulaicha, in the past, milkfish was also used as a symbol/sign of liking a girl. A man who liked the girl would usually hang milkfish on a wooden fence or on a girl's house tree, if the hanged milkfish was taken by the girl's family, it meant that the girl's family accepted the man's intention. However, once again, this tradition was no longer prevail today, since if milkfish was hung on the fence it was not the person who will take the milkfish but the cat.

The region becoming the center of the sale of milkfish ahead of the Chinese New Year celebration was at Jalan Sulaiman, Rawabelong, West Jakarta. Milkfish sellers here were from various regions. They sold along the sidewalk of Jalan Sulaiman just before the Chinese New Year.

According to Yohannes, milkfish sellers in Rawabelong, people who bought milkfish were mostly Betawi people who were not Chinese descent. He continued, there were differences between Chinese people and Betawi people regarding milkfish. Chinese people usually use milkfish to worship such as "nyekar" while Betawi people bought it to cook Pindang Bandeng and eat it with their families.

Big milkfishes were the most delicious ones to cook as pindang. The big milkfish for Chinese people symbolized the prosperity and abundant sustenance. This large milkfish contained a lot of fat which would add the delicious of pindang sauce.

During the Chinese New Year, the large and high quality milkfishes could be easily obtained. Milkfish sold before the Chinese New Year was different from milkfish sold everyday. Chinese New Year milkfish were large in size, because the milkfish was kept purposively for a year and was sold just before Chinese New Year. While milkfish sold daily was small to medium-sized. At this time, many Betawi people came to buy milkfishes. Those who had a lot of money would buy as much milkfish as possible to cook on their own and certainly did not forget to deliver to their parent and beloved parent-in-law. 
The history abovementioned showed that milkfish had a synergy in ethnic diversity in Indonesia. In this case, there was acculturation of Chinese culture and Betawi culture. The said acculturation was demonstrated in Chinese New Year celebration wherein the tradition of eating milkfish not only became the property of the Chinese ethnic, but also became a part of the Betawi ethnic.

\subsection{Description of Culinary}

According to the Indonesian Dictionary, the culinary word is related to cooking. But in general, culinary is a processed product in the form of dish and food. The difference between dish and food according to Bang Yoyo from LKB was in the complexity of the preparation. Culinary refers to preparation with various basic ingredients and its cooking process is long and eaten as heavy food.

Meanwhile, Food is usually processed quickly and eaten as a snack.

Pindang Bandeng as a Non-Material Culture Heritage is included in the Betawi dish category having various ways to cook it. In one Betawi community, they cooked it by burning/roasting ingredients but the other one cook it by sauting the ingredients.

Administratively, the Betawi region is divided into 3 parts, namely: Central Betawi, Edge Betawi and Coastal Betawi. According to Bang Yoyo which was based on the culture map, the Betawi tribe covers up to Batujaya (Karawang), Mauk, Gunung Sindur, Gunung Putri, Depok and Cibinong areas. Do not feel excluded if the Betawi community were displaced to those areas, since they were still included in the region of the Betawi culture map.

In this study, the Betawi region becoming a basic of this study was the Central Betawi region. The Pindang Bandeng recipe used in this study was based on a recipe that prevails in the Central Betawi region, wherein the processed seasonings was by burned/roasted first instead of sauted. The color of the blackish sauce on Pindang Bandeng came from sweet soy sauce. The sauce was rich of spices and made by a very diverse composition of seasonings, including shallot, garlic, red chili, cayenne chili, turmeric, galangal, ginger, lemongrass, salam leaf, tamarind, brown sugar, and vegetable starfruit.

Pindang Bandeng had completed tastes, namely spicy, sweet, salty and fresh sour. The sour taste of it came from vegetable starfruit. Instead of vegetable starfruit, we could use tomatoes. In addition, the nutrient content of milkfish was better than that of Salmon. The Omega-3 content of milkfish was six times higher than that of salmon. Also, the healthy fat content in the stomach of milkfish was considered high enough, so that milkfish could be the best choice as a consumption fish.

\subsection{Preparation of Standard Recipe}

Based on the recipe from Mrs. Cucu Sulaicha and and Mrs. Anisa Diah Sitawati, Pindang Bandeng dish was divided into two parts, namely ingredients and seasonings.

The recipe was as follow.

\section{Ingredients:}

$1 \mathrm{~kg}$ fresh milkfish, clean it, cut each fish into 3 parts

2 tablespoons lime juice

1 tablespoon salt

1 tablespoon tamarind water

1 tablespoon brown sugar

4 tablespoons sweet soy sauce

5 vegetable starfruits, cut into 2 sections longitudinally 
$400 \mathrm{ml}$ water

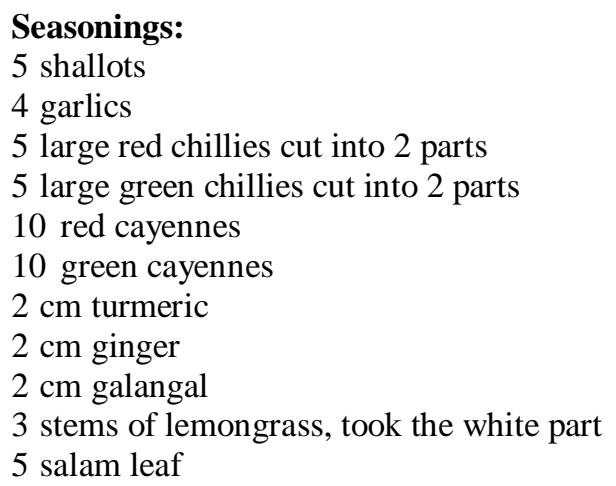

Instructions:

- $\quad$ Rub the milkfish with lime juice and half of salt. Let them marinate for 15 minutes. Set it aside.

- $\quad$ Roast all seasonings until they are fragrant and blackish, lift.

- Chop coarsely all seasonings.

- $\quad$ Boil the water, add the roasted and roughly chopped seasonings, milkfish, remain salt, and sweet soy sauce. Mix well, boil again.

- $\quad$ Add tamarind water and vegetable starfruits, mix well. Simmer until all ingredients are cooked. Lift.

- $\quad$ Serve warm.

\subsection{For 8 servings}

\section{Presentation}

In this research, the potential of Pindang Bandeng was expected to become a BetawiChinese Acculturation Food Iconic Product so as it can be used as a typical food of Betawi culinary tourism and it is continue to be socialized to the community to be sustained.

According to Mrs. Cucu Sulaicha, in Betawi if you cook Pindang, it was milkfish; if you cook milkfish, it was Pindang. In other regions, if you cook Pindang, it coud be various kinds of fish. Furthermore, in Betawi, spices to cook milkfish may not be sauted or cooked by coconut milk but must be burned/roasted.

\section{Culinary Distribution Areas}

The Betawi community consists of three characters:

First, the coastal area raising a maritime culture. Second, the middle area raising a populist culture. Third, the edge area raising an agrarian culture.

For milkfish itself, the distribution areas are in Rawabelong, Cengkareng, Senayan and Mauk, Tangerang (Bang Rudi, LKB). But since milkfish is a fish easily live in the coastal waters of Jakarta, this fish is easy to find anytime, not only when Chinese New Year. 
However, it is undeniable that when Chinese New Year the large-sized milkfish will emerge, since they are purposively kept for a year.

\section{Culinary Culture Values}

\section{Philosophy}

\section{From the Betawi people side:}

Milkfish is the choice for Betawi community to be made pindang since this fish is one of fishes easily lives in the coastal waters of Jakarta. On normal days we can find milkfish in traditional markets with a small size, while during Chinese New Year there are a lot of milkfish with large and super large sizes (around 2 - 7 kilograms), with price reaches up to $100,000 \mathrm{IDR} / \mathrm{kg}$.

According to old people' story, eating milkfish has its own philosophy. The milkfish was known having many burrs and if you eat milkfish, it was expected that you will get more sustenances. Furthermore, milkfish has a lot of fat, especially fish with large size, so if that fish were not consumed in a day, it can be stored for the next day. Fat in milkfish can preserve it from being thrown away.

Furthermore, milkfish was a favorite one in Chinese New Year dishes and it had a philosophy as a part of the natural elements must be exist and was a symbol of life-saving and youthful. In a deeper meaning it was a symbol of respect. A family member who did not deliver milkfish to older people such as parent and parent in-laws was considered asa not to have a politeness.

Pindang Bandeng had more interesting philosophy. According to old people' story, Pindang Bandeng was a dish to test a prospective daughter-in-law. During the Chinese New Year, the said prospective daughter-in-law who brought Pindang Bandeng to prospective male-in-law signed that she was very concerned with her parent-in-law. And the story of it was as follows:

First. Dilligent Test. To obtain a large and fat milkfish, we can obtain it in the morning. Thus, it was tested whether or not the prospective daughter-in-law woke up early. If she could not do it, she would not get the desired milkfish. Otherwise, she passed the first test.

Second. Persistence Test. It was not easy to cook Pindang Bandeng with an appropriate flavor on low heat. If the prospective daughter-in-law did it persistently and patiently with good result, she passed the test.

Third. Sensitivity Test. The sweet, spicy, salty and sour tastes of Pindang Bandeng must be appropriate. If the prospective daughter-in-law cooked it well, it meant the sensitivity of the woman was good. She passed the third test.

Fourth. Neatness Test. After the three tests above have been successfully passed, the last test was very determining. After the prospective daughter-in-law got large and fat milkfish, cooked it diligently in a right way with appropriate taste, then neatness in serving the dish was very important. The Finishing Touch in serving Pindang Bandeng dish would determine whether or not the prospective daughter-in-law was a perfect woman who deserves to be a daughter-in-law. If she did it neatly, she passed the test and vice versa. 
Briefly, for Betawi community and its surroundings, it was not yet called Chinese New Year if there was no Ang Pau and Pindang Bandeng. Pindang Bandeng was a symbol of prosperity, while the way to cook it was a symbol of the soul maturity of the one who cook it.

\section{From the Chinese side:}

According to Yohanes, milkfish seller in Rawabelong, milkfish in Chinese New Year celebration in Chinese community in Indonesia were mainly used for worship namely, nyekar. Some of them cooked it to eat when the feast day. The bigger the fish purchased, the greater the sustenance expected to be obtained in the coming year.

Based on the Chinese beliefs believing in 12 zodiacs, generally they always provide 12 kinds of dishes and 12 kinds of cakes representing the said 12 zodiacs. The dishes served were usually the dishes having meaning related to prosperity, longevity, happiness and safety.

In the tradition of the Chinese living in Indonesia, one of the main dishes always available during Chinese New Year celebration was milkfish. Fish for them meant a symbol of prosperity and sustenance. The word "fish" or " $\mathrm{Yu}$ " in Mandarin accent meant sustenance. They hope that they would gain prosperity and sustenance in the newyear. Because of this, in many Chinese restaurants there was usually a goldfish aquarium symbolized sustenance covered by abundant gold.

In the tradition of Chinese-style large banquet, fish dish was always served at the end of it as a symbol of abundant sustenance in the future. Fish was served completely from head to tail. If there was an honor guest, the fish head would be directed to the guest. And ff we attend a large banquet and find it directed to us, we do not need to be worry, since it is an honor to us.

\section{Culinary Culture Heritage//Maestro/Successor}

This research was conducted using informants with certain conditions, namely experts who have deep knowledge of Betawi typical traditional culinary. The main informants on this research were the Maestro, Mrs. Cucu Sulaicha and Mrs. Anisa Diah Sitawati, who have expertisement in the cooking field. They both join in the management of the Betawi Cultural Institute (LKB). Other informants were Mr. Yahya Andi Saputra, Mr. Heryus Saputra and Mrs. Suzen HR Lumban Tobing,

Another Betawi Maestro, Mr. Yahya Andi Saputra is a Betawi cultural researcher and administrator of the Betawi Cultural Institute (LKB) and chairman of the Jakarta Oral Tradition Association (Asosiasi Tradisi Lisan - ATL). Mr. Yahya, as we called him Bang Yahya, is also the author of Betawi books. His books are Gelembung Imaji (Kumpulan Puisi, 1999), Beksi: Maen Pukulan Khas Betawi (2002), Upacara Daur Hidup Adat Betawi (2002), Sejarah Perkampungan Budaya Betawi: Demi Anak Cucu (2014), Sindir Sindir (Kumpulan Puisi, 2016). Furthermore, other informants were Mr. Heryus Saputro, a senior journalist, humanist and book writer; and Mrs. Suzen HR Lumban Tobing, a Lecturer at the Jakarta Art Institute. 


\section{Conclusion}

Chinese New Year Holidays for Chinese are considered not just ordinary annual ritual and culture, but also integrate with trust. Just like food for traditional or other religious ceremonies, the Chinese New Year's typical food is loaded with various kinds of symbolic meanings.

Chinese New Year in Indonesia has subjected acculturation/assimilation with local culture, in this case Betawi culture. It was proved by the mentioning of "Lebaran China" from the Betawi people for Chinese New Year. It meant that the Betawi people considered Chinese New Year was a part of their culture. Therefore, Betawi people also celebrated it, not just participated in the Chinese New Year night market and carnival, but many of them joined in celebrating and eating the Chinese New Year typical food since the mid-19th century.

It was no wonder if the milkfish was also present as a must culinary in the Chinese New Year tradition of Chinese in Indonesia. As a part of Indonesian culinary history, milkfish in Chinese New Year celebration were usually processed into Pindang Bandeng, which was a genuine dish from Betawi by using sweet soy sauce and has a plurality of fairy tales and stories. As a culinary dish, especially on Java, fish-flavored culinary in the Indonesian culinary tradition could be considered rare, unlike in other regions in Indonesia such as Sumatra or Sulawesi which have a number of fish-flavored culinary recipes. The pindang itself, for example, along in South Sumatra, tended not to use sweet soy sauce and was more strongly influenced by Malay culture. Pindang Bandeng in the style of Peranakan in Betawi was an assimilation/mixing of several cultures so as to produce unique culinary dish as a culinary culture heritage of the Betawi ethnic.

Accordingly, from the results and discussion above, it could be concluded that Pindang Bandeng could be raised its potential as the Betawi-Chinese Acculturation Food Iconic Product, wherein it was a food product of the blend of Betawi and Chinese cultures especially during Chinese New Year because it was identical with milkfish processed into Pindang Bandeng. Thus, Pindang Bandeng became an Icon of Chinese New Year celebration in Indonesia.

\section{Acknowledgement}

Bismillahirrahmanirrahim. All praise and gratitude for the presence of Allah SWT due to His Grace and Gift, I can finish this research well. This research is an Internal Grant from Institut Ilmu Sosial dan Manajemen STIAMI, Jakarta. This research entitled "Potential of Pindang Bandeng as The Betawi-Chinese Acculturation Food Iconic Product".

All efforts I did in this research will be meaningless without the guidance, assistance, and support has been given by various parties. Therefore, the deepest gratitude I dedicated to Institut Ilmu Sosial dan Manajemen STIAMI, Jakarta, which has provided an opportunity to obtain the Internal Grant. And many thanking I dedicated to other parties cannot be mentioned one by one.

Finally, I realized that this research still having lack of disadvantages, hence I expected the constructive suggestions and criticisms to improve this research. Hopefully this research can be useful for readers, and can be used as a positive input for science in the field of tourism. 


\section{References}

\section{Books:}

[1]. Ahmad Hanfan. 2017. Membangun Keunggulan Produk Ikonik Untuk Meningkatkan Kinerja Pemasaran UMKM. Derema Jurnal Manajemen Vol. 12 No. 2, September.

[2]. Anselm Strauss And Juliet Corbin. 2015. Basics Of Qualitative Research: Techniques And Procedures For Developing Grounded Theory. Fourth Edition. SAGE Publications, Inc., United States Of America.

[3]. Holt, D. B. 2004. How Brands Become Icons: The Principles Of Culture Branding, Harvard University Press, Harvard MA, United States.

[4]. Koentjaraningrat. 1990. Pengantar Ilmu Antropologi. Rineka Cipta, Jakarta.

[5]. Budiasih, I Gusti A. N. 2014. Metode Grounded Theory Dalam Riset Kualitatif. Jurnal Ilmiah Akuntansi Dan Bisnis, Vol. 9, No. 1.

[6]. Strauss, Anselm Dan Corbin, Juliet. 2003. Dasar-Dasar Penelitian Kualitatif: Tata Langkah Dan Teknik-Teknik Teoritisasi Data. Pustaka Pelajar, Yogyakarta.

\section{Internet Sources:}

[1]. Https://Kbbi.Web.Id/

[2]. Https://Radhikcool.Wordpress.Com/2008/02/17/Pindang-Bandeng-Yang-Penuh-Dengan-Filsafat/

[3]. Https://Lifestyle.Okezone.Com/Read/2017/10/25/298/1802163/Food-Story-Pindang-BandengKuliner-Betawi-Yang-Dapat-Pengaruh-Tiongkok-Jangan-Lupa-Jajal-Resepnya

[4]. Http://Zhushimuyu.Blogspot.Com/2015/12/Pindang-Bandeng.Html

[5]. Https://Www.Kompasiana.Com/Mang_Kani/550d7f19a333112d1c2e3c8c/Bandeng-Imlek-OrangBetawi

[6]. Https://Www.Kompasiana.Com/Estherlima/5528c421f17e610e058b45bb/Tradisi-PindangBandeng-Imlek

[7]. Http://Djpdspkp.Kkp.Go.Id/Artikel-805-Makna-Bandeng-Dalam-Sajian-Imlek.Html

[8]. Https://Www.Jia-Xiang.Biz/Ikan-Bandeng-Simbol-Rumitnya-Kehidupan/ 